Article

\title{
Ethmalosa fimbriata (Bowdich 1825), a Clupeid Fish That Exhibits Elevated Batch Fecundity in Hypersaline Waters
}

\author{
Julian Döring ${ }^{1, *}$ (D), Maik Tiedemann ${ }^{2}$, Moritz Stäbler ${ }^{1}$, Hans Sloterdijk ${ }^{1}$ and Werner Ekau ${ }^{1}$ \\ 1 Leibniz Centre for Tropical Marine Research, Fahrenheitstraße 6, 28359 Bremen, Germany; \\ moritz.staebler@leibniz-zmt.de (M.S.), hans.sloterdijk@leibniz-zmt.de (H.S.), \\ werner.ekau@leibniz-zmt.de (W.E.) \\ 2 Thünen-Institute (TI), Institute of Sea Fisheries, Federal Research Institute for Rural Areas, \\ Forestry and Fisheries, Palmalle 9, 22767 Hamburg, Germany; maik.tiedemann@thuenen.de \\ * Correspondence: julian.doering@leibniz-zmt.de or julian.doering@me.com; Tel.: +49-421-23-800-93
}

Academic Editor: Adelino V. M. Canario

Received: 11 July 2017; Accepted: 14 August 2017; Published: 18 August 2017

\begin{abstract}
Little is known about the concerted influence of temperature and salinity on the fecundity of clupeid fishes. Due to a globally changing climate, both physical parameters might act as stressors, severely affecting the reproductive potential of clupeid fish populations inhabiting tropical estuaries. Differences in relative batch fecundities, the gonado-somatic index, and the condition index of bonga shad (Ethmalosa fimbriata) were analysed in individual females sampled at the Senegalese coast and inside the inverse Sine Saloum estuary, where salinity increases upstream in all seasons. Multiple linear regression models on fecundity and gonadal energy storage show that clupeids can adapt towards increasing their reproductive investment at temperatures $\left(26-30^{\circ} \mathrm{C}\right)$ and salinities (42-51), which by far exceed marine conditions, in an effort to maximize recruitment success. This reproductive strategy, however, is accompanied by a trade-off between reproductive effort and somatic growth, which ultimately limits the species' reproductive potential inside the estuary. The observed high variability in batch fecundities might be a viable mechanism to adjust to fluctuating and rather extreme environmental conditions. Understanding the spawning biology of exploited clupeid fishes in drastically changing environments is crucial for evaluating the reproductive potential of stocks at the outer reach of their physiological performance curve.
\end{abstract}

Keywords: global change; Senegal; inverse estuary; reproductive potential; temperature; salinity; spawning; fecundity; condition; trade-off

\section{Introduction}

While spawning traits of marine fish species in marine, brackish, or fresh waters are extensively studied [1,2], little is known about reproductive characteristics of fishes under hypersaline conditions exposed to salinities $>40$. Such extreme conditions require elevated maintenance costs for osmoregulation and are especially challenging for the mature female [3,4], as well as for its eggs and larvae [5,6]. Spawning as such is metabolically one of the most demanding activities in the lifetime of female fishes $[7,8]$, making reproduction under hypersaline conditions an energetically expensive endeavour [9].

Adaptive phenotypic plasticity is a valuable mechanism for populations to deal with rapid environmental fluctuations such as changes in salinity [10]. Clupeids are generally able to cope with extreme environmental conditions by varying their life history traits via either genetic changes or 
phenotypic plasticity [11,12]. For example, Baltic sprat (Sprattus sprattus balticus, Schneider 1908) exhibit a decrease in batch fecundities along a declining salinity gradient within the brackish Baltic Sea [13-17].

Temperature not only has significant effects on metabolic rates and fecundities in clupeid fishes, but also on egg and larval development [18-20]. Under conditions of extreme temperature and salinity, adult survival rates of marine fishes, as well as egg and larval development, are impaired [21,22]. At the boundary of its physiological performance curve an adult fish is thus forced to budget between survival and reproductive capacity [23]. Therefore, in a heterogeneous environment a species' reproductive potential may exhibit strong variations spatially as well as temporally $[19,24]$.

Little is known about the concerted influence of temperature and salinity on an individual's condition and growth, and consequently on the amount of eggs produced $[16,25,26]$. Water temperature has been identified as a factor influencing fecundity in marine fishes. The influence can be either passive through its regulatory function of phytoplankton abundances, and thus food availability, and/or active through altering the individual's metabolic rate $[8,27,28]$. In mature fish, feeding conditions directly affect the individual's condition and the amount of energy that can be put into reproduction $[8,29,30]$. Furthermore, osmoregulation processes are energetically expensive and may therefore interfere with species' reproductive traits at elevated salinities [4,31]. All of these variables potentially affect subsequent recruitment success and have to be considered when evaluating a species' reproductive potential at the boundary of its physiological optimum range [8,32].

A variety of studies lead to the conclusion that the bonga shad (Ethmalosa fimbriata, Bowdich 1825) is locally adapted to cope with a wide range of environmental conditions in terms of its morphology, growth, and reproductive traits [9,25,33-36]. In different areas along the West African coast, E. fimbriata spawns either in the sea [34], or in estuaries and lagoons [36]. A physiology adapted to euryhaline conditions allows the species to cope with varying salinities in these diverse habitats, allowing it to tolerate salinities from around 0 to 97 [9] and even to reproduce in waters with salinities up to 66 [37]. The species is distributed in West African Atlantic waters from Mauritania to Angola [38,39], and despite its marine origin, is highly abundant in estuaries, deltas, and lagoons [37]. It is one of the most important fishes targeted by artisanal fisheries in Cameroon, Ivory Coast, Nigeria, and Senegal [40-42].

Especially in Senegalese waters, E. fimbriata has to endure a wide range of varying environmental settings. Former studies demonstrated that the species spawns all year round in the lower and middle reaches of the Saloum River [43,44], an inverse hypersaline environment with monthly fluctuations in temperature and salinity [45]. The rather extreme environmental conditions in the Sine Saloum estuary were used to investigate the reproductive response of a clupeid fish at the outer reach of its physiological performance curve. Due to a globally changing climate the inversion of estuaries in other parts of the dry tropics can be expected in the near future [45-47]. Thus, understanding the spawning biology and adaptation potential of commercially important fish species is the key to predict inevitable impacts on the ecosystems and local fisheries.

The current study focused on how this hypersaline environment influences the spawning biology of female E. fimbriata and how the species is adapted to cope with the aforementioned extreme salinity conditions. More specifically, it was attempted to reveal possible energetic trade-offs accompanied by inhabiting and spawning in hypersaline environments. Consequently, variations in somatic condition, gonado-somatic index, and in the batch fecundity of female E. fimbriata were investigated, along a spatial and temporal salinity and temperature gradient at the Senegalese coast and within the hypersaline Saloum estuary.

\section{Results}

\subsection{Environmental Parameters}

Night-time surface water temperatures at the three sampling sites steadily increased throughout the sampling period, peaking in October. Surface water temperatures were generally higher at Foundiougne than at Joal, with intermediate values recorded at Djifer. At the beginning of the 
sampling period (February), salinity was determined to be 39 at Foundiougne as well as at Djifer. In the following months, salinity increased steeply at Foundiougne, eventually peaking in July at 54 until it dropped to 43 in September and October. At Djifer, salinity peaked at 43 in July and August before dropping down to 32 in September. The tropical open ocean's salinity at Joal negligibly fluctuated around 37 throughout the entire sampling period (Figure 1).

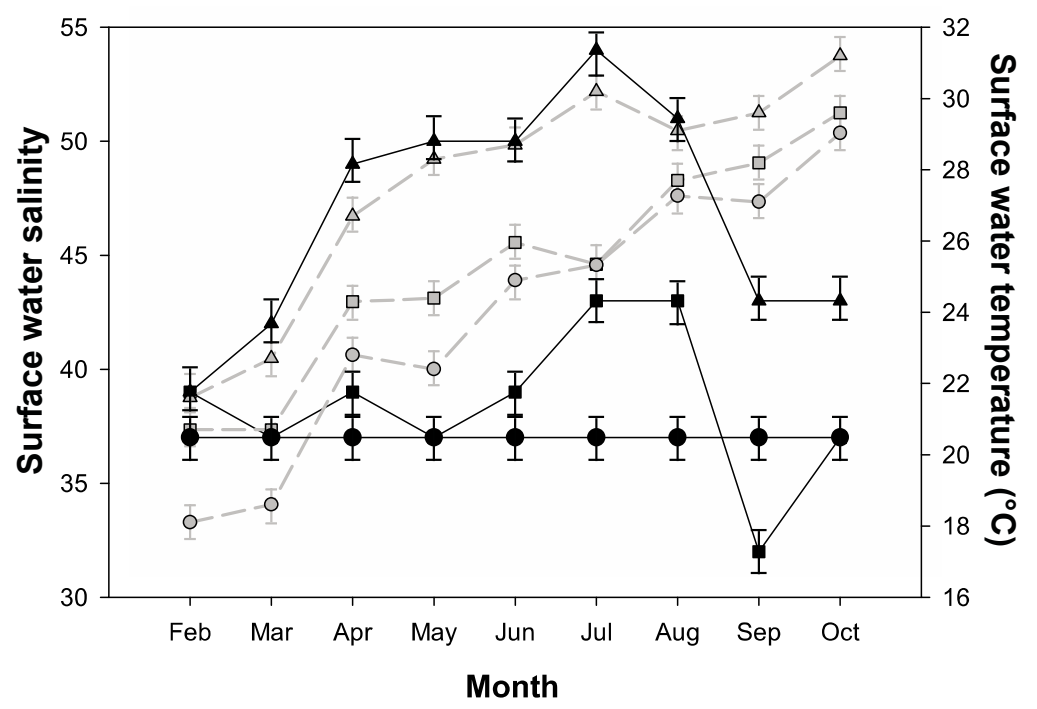

Figure 1. Night-time surface water temperatures ( \pm Standard Error (SE); grey) and surface water salinities ( \pm SE; black) of the Atlantic Ocean and the Saloum River as recorded at Joal (circles), Djifer (squares), and Foundiougne (triangles) throughout the sampling period.

\subsection{Length-Weight Relationship}

A total of 1108 female E. fimbriata were sampled for this study; 919 specimens were identified as stage I-IV and the ovaries of 189 individuals stored hydrated oocytes (Table 1). Different power functions were calculated to describe the length-weight relationships of females sampled at the three sampling sites (Figure 2). Comparison of linear growth models revealed that females sampled inside the Saloum River (Foundiougne) weighed significantly less at a certain length than their counterparts sampled at the river's mouth (Djifer) and at the Atlantic coast (Joal) (Analysis of Covariance (ANCOVA), $\mathrm{F}_{(3,1107)}=3837.104, p<0.0001$; Tukey Honest Significant Difference (HSD), $p<0.001$ ). The length-weight relationship of all sampled females across all sampling sites could be described by the following function (Student's $t$-test, $p<0.05, \mathrm{r}^{2}=0.90, n=1108$ ):

$$
W_{\mathrm{W}}=0.0015 \times L_{\mathrm{T}}^{3.62}
$$




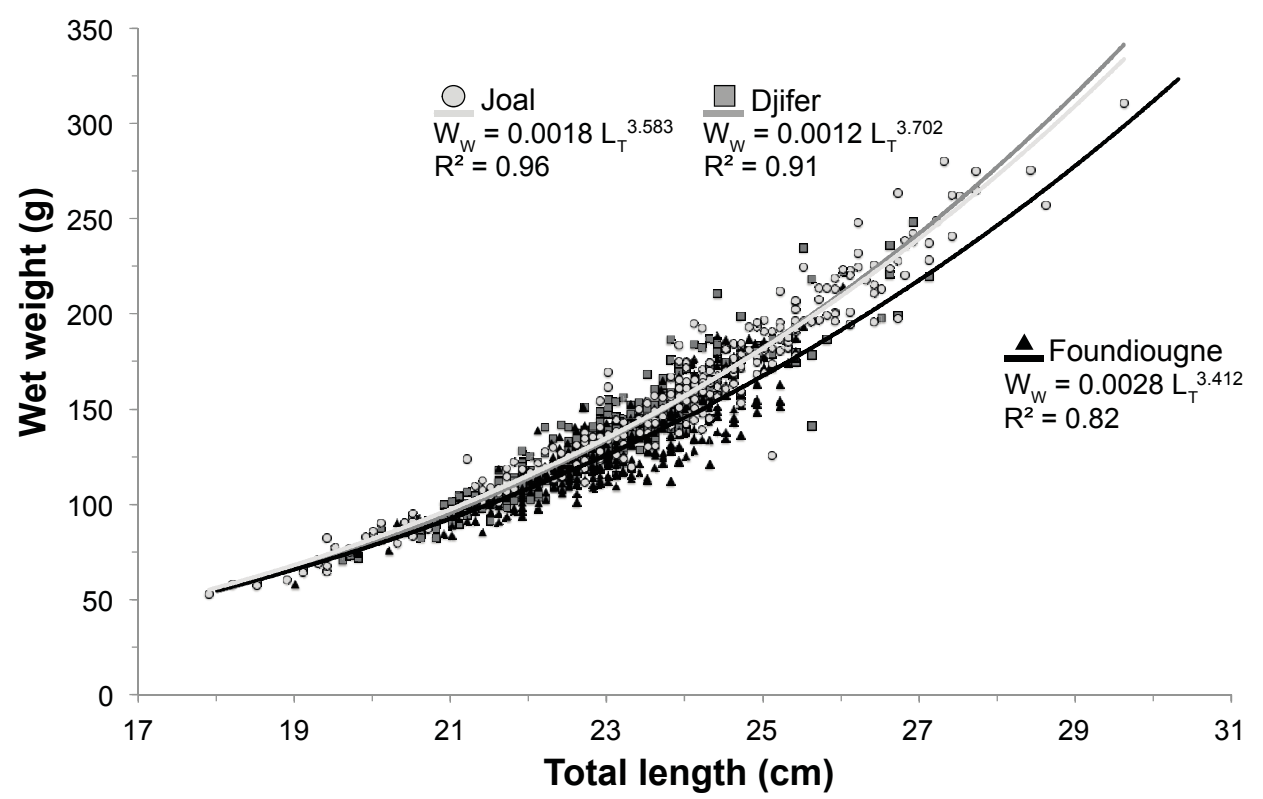

Figure 2. Length-weight relationships for all females sampled at Joal (Senegalese coast), Djifer (Saloum River's mouth), and Foundiougne (Saloum River's middle reaches).

Table 1. Monthly sampling sizes for immature (stage I-IV) and hydrated (stage V) female E. fimbriata at the three sampling sites: Joal (Senegalese coast), Djifer (Saloum River's mouth), and Foundiougne (Saloum River's middle reaches).

\begin{tabular}{|c|c|c|c|}
\hline Sampling Site & Sampling Month & Stage I-IV & Stage V \\
\hline \multirow{9}{*}{ Joal } & February & & \\
\hline & March & 30 & 8 \\
\hline & April & 24 & 3 \\
\hline & May & 44 & 20 \\
\hline & June & 35 & \\
\hline & July & 42 & \\
\hline & August & 26 & \\
\hline & September & 34 & \\
\hline & October & 29 & \\
\hline \multirow{9}{*}{ Djifer } & February & 16 & 8 \\
\hline & March & 57 & 2 \\
\hline & April & 19 & 25 \\
\hline & May & 38 & \\
\hline & June & 32 & 7 \\
\hline & July & 37 & 4 \\
\hline & August & 37 & \\
\hline & September & 24 & \\
\hline & October & 27 & \\
\hline \multirow{9}{*}{ Foundiougne } & February & 52 & 2 \\
\hline & March & 20 & 15 \\
\hline & April & 66 & 4 \\
\hline & May & 44 & 2 \\
\hline & June & 40 & 5 \\
\hline & July & 26 & 23 \\
\hline & August & 42 & 29 \\
\hline & September & 51 & 3 \\
\hline & October & 27 & 29 \\
\hline
\end{tabular}




\subsection{Reproductive Parameters}

\subsubsection{The Condition Index and the Gonado-Somatic Index}

A statistical analysis revealed not only significant monthly differences in condition index (K) for each station but also significant differences between stations for each month apart from February. At Djifer, the condition of female fish (stage I-IV) peaked in February as well as in July (Analysis of variance (ANOVA), $\mathrm{F}_{(8,286)}=7.50, p<0.0001$; Tukey HSD, $\left.p<0.05\right)$. Comparably, the mean $\mathrm{K}$ of females sampled at Foundiougne was significantly higher in February and in July than in most other months, except in March and June (ANOVA, $\mathrm{F}_{(8,367)}=10.92, p<0.0001$; Tukey HSD, $p<0.05$ ). Females were in a significantly better condition at Djifer than at Foundiougne in all months except for October (Tukey HSD, $p<0.05$ ). The mean $\mathrm{K}$ of females sampled at Joal was significantly higher than the one of individuals sampled at Foundiougne in all months except for March, April, and July (Tukey HSD, $p<0.05$ ). Still, the mean condition of immature females was always lowest in specimens sampled inside the Saloum River's middle reaches at Foundiougne (Figure 3).

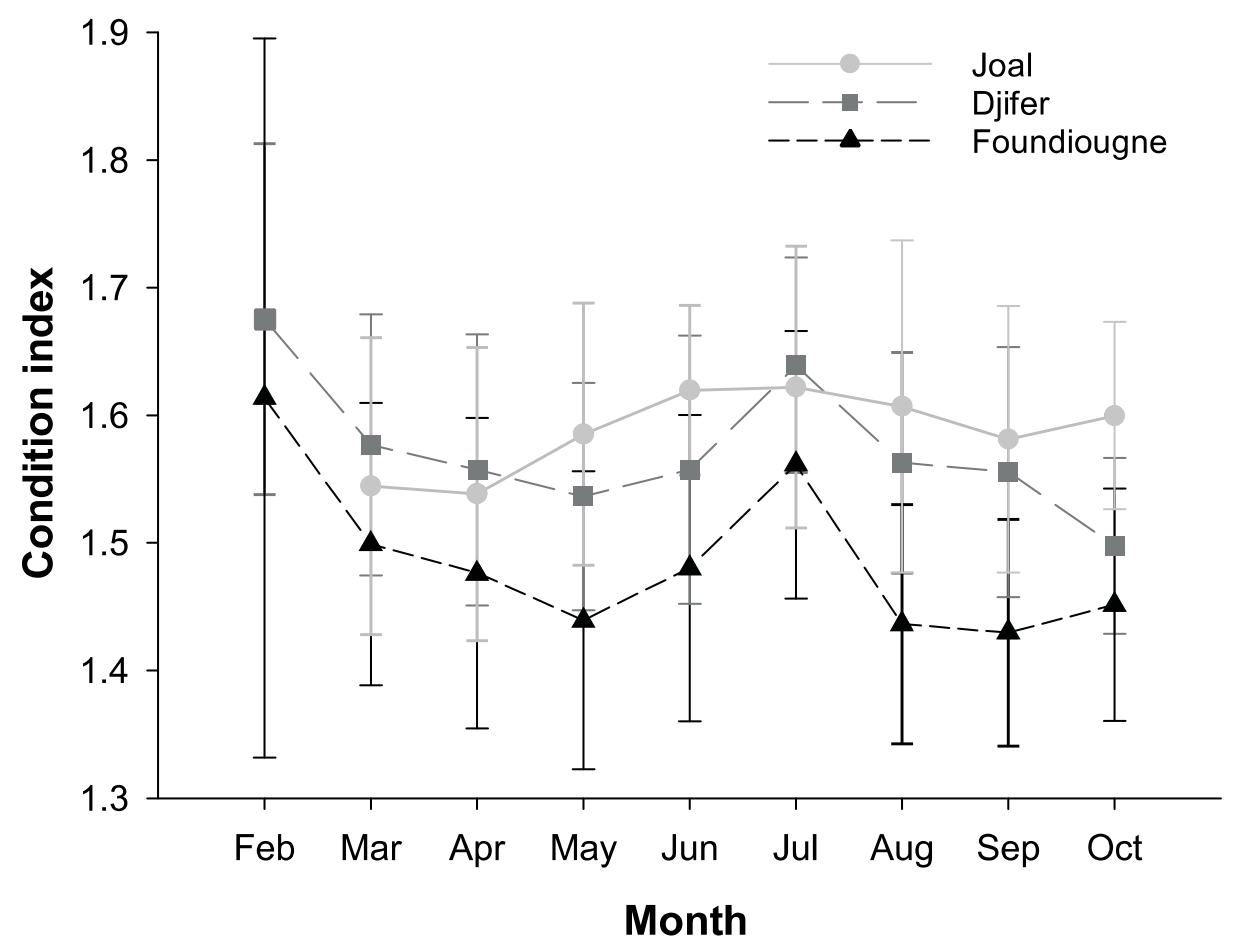

Figure 3. Mean ( \pm Standard Deviation (SD)) monthly changes in condition index (K) of stage I-IV female E. fimbriata sampled at Joal (Senegalese coast), Djifer (Saloum River's mouth), and Foundiougne (Saloum River's middle reaches).

The condition index $\left(\mathrm{K}_{\text {hyd }}\right)$ of stage $\mathrm{V}$ showed a decreasing trend at all sampling sites during the progression of the sampling period (February to October). The mean condition of female spawners was significantly higher in February than in September $\left(\mathrm{ANOVA}, \mathrm{F}_{(8,111)}=3.39, p<0.01\right.$ ) (see Appendix A Table A1 for Tukey HSD results). Comparably, $\mathrm{K}_{\text {hyd }}$ at Joal (ANOVA, $\mathrm{F}_{(2,30)}=0.46, p=0.64$ ) and Djifer (ANOVA, $\mathrm{F}_{(4,45)}=1.82, p=0.14$ ) was higher in March than in all other sampling months (Figure 4). 

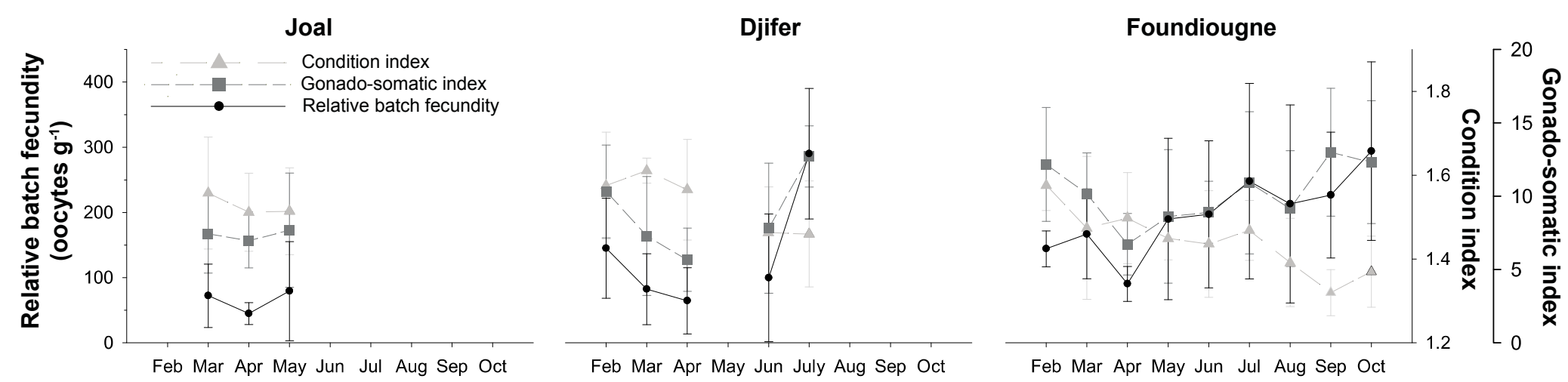

Month

Figure 4. Mean $( \pm \mathrm{SD})$ relative batch fecundity $(\mathrm{RBF})$, condition index $\left(\mathrm{K}_{\mathrm{hyd}}\right)$, and gonado-somatic index $\left(\mathrm{I}_{\mathrm{G}}\right)$ of stage $\mathrm{V}$ female $E$. fimbriata per sampling site and month. 
At Djifer (ANOVA, $\mathrm{F}_{(4,45)}=7.33, p<0.001$ ) and Foundiougne (ANOVA, $\left.\mathrm{F}_{(8,111)}=2.05, p<0.05\right)$, the mean gonado-somatic index $\left(\mathrm{I}_{\mathrm{G}}\right)$ of stage $\mathrm{V}$ females reached a significant minimum in April and subsequently increased again (Appendix A Table A1). At Joal (ANOVA, $\mathrm{F}_{(2,30)}=0.025, p=0.98$ ), $\mathrm{I}_{\mathrm{G}}$ remained constant throughout the three months in which spawning females could be sampled.

\subsubsection{Batch Fecundities}

Fecund females were sampled in the size ranges $\left(\mathrm{L}_{\mathrm{T}}\right)$ of $23.1 \mathrm{~cm}-27.5 \mathrm{~cm}, 20.8 \mathrm{~cm}-26.9 \mathrm{~cm}$, and $19.9 \mathrm{~cm}-28.3 \mathrm{~cm}$ at Joal, Djifer, and Foundiougne, respectively. The variance in the number of produced oocytes per spawner was generally high throughout the three sampling sites: absolute batch fecundity (ABF) at Joal ranged between 3316 hydrated oocytes in a $25.4 \mathrm{~cm}$ individual and 66,375 ripe oocytes in a $26.1 \mathrm{~cm}$ long female, both sampled in May. At Djifer, a $23.3 \mathrm{~cm}$ female sampled in April exhibited the lowest ABF with 2200 oocytes, while in February a similarly sized individual $(23.5 \mathrm{~cm})$ showed an ABF of 39,490 hydrated oocytes. At Foundiougne ABF ranged between 3160 oocytes in a $25.5 \mathrm{~cm}$ female and as much as 85,410 oocytes in a $24.8 \mathrm{~cm}$ specimen, both sampled in July. An effect of the female's size on the number of produced oocytes was controlled for by applying ANCOVA on the linear regressions between total length $\left(\mathrm{L}_{\mathrm{T}}\right)$ and $\mathrm{ABF}$, as well as ovary free body weight $(\mathrm{OFBW})$ and ABF. The assumption of parallel lines was met. The intercept of $L_{T}$ and $A B F$ was significantly higher in females sampled at Foundiougne and Djifer than at Joal (ANCOVA, $\mathrm{F}_{(3,188)}=18.4923, p<0.0001$, Tukey HSD, $p<0.0001$ ). Also, the intercept of OFBW and ABF was significantly higher at Foundiougne than at Djifer and Joal (ANCOVA, $\mathrm{F}_{(3,188)}=16.8477, p<0.0001$, Tukey HSD, $p<0.01$ ). Therefore, ABF values were always highest at Foundiougne for the same female size.

In spite of considerable inter-individual variation, significant monthly variations in relative batch fecundity (RBF) could be observed. Whereas no monthly differences in mean RBF were detected in females sampled at Joal (ANOVA, $\left.\mathrm{F}_{(2,30)}=0.37, p=0.69\right)$, fecundity was significantly lower in February than in April at Djifer. During the consecutive months mean RBF increased again at this sampling site: RBF was determined to be significantly higher in July than in all other sampling months (ANOVA, $\left.\mathrm{F}_{(4,45)}=8.45, p<0.0001\right)$. At Foundiougne a similar pattern emerged; RBF was significantly higher in October than in April (ANOVA, $\left.\mathrm{F}_{(8,111)}=2.04, p<0.05\right)$ (Figure 4; Appendix A Table A1).

\subsubsection{Correlation of Reproductive Parameters with Temperature and Salinity}

The applied multiple linear regression models revealed concerted effects of temperature and salinity explaining $90 \%, 25 \%$, and $97 \%$ of the observed variances in $\mathrm{RBF}, \mathrm{K}_{\mathrm{hyd}}$, and $\mathrm{I}_{\mathrm{G}}$, respectively. Temperature and salinity had opposing effects on RBF. While temperature had a positive and quadratic effect on the square root transformed data on RBF, the relationship between salinity was negative and quadratic (Table 2). The apex point of the function was determined for waters warmer than $30^{\circ} \mathrm{C}$ and at salinities of around 46. The model results on $\mathrm{I}_{\mathrm{G}}$ also revealed mirroring effects of temperature and salinity on the ratio of gonad weight to female body weight. In both models the intercept did not pose as a significant term. Conversely, temperature had a linear and negative effect on $\mathrm{K}_{\text {hyd }}$ in E. fimbriata, while salinity exhibited a negative and quadratic effect on this somatic energy storage parameter. A minimum in $\mathrm{K}_{\text {hyd }}$ became apparent in females spawning in waters with surface temperatures around $30^{\circ} \mathrm{C}$ at a salinity of 46 (Appendix B Figure A4). 
Table 2. Results of the multiple linear regression models of relative batch fecundity (RBF), condition index $\left(\mathrm{K}_{\text {hyd }}\right)$, and gonado-somatic index $\left(\mathrm{I}_{\mathrm{G}}\right)$ against linear and quadratic terms of surface water temperature $\left(T, T^{2}\right)$ as well as surface water salinity $\left(S, S^{2}\right)$. Estimates of the parameters for the least adequate models, including only significant terms, are shown, together with their respective standard errors and p-values. RSE: Residual Standard Error.

\begin{tabular}{cccccccccc}
\hline & \multicolumn{3}{c}{ Relative Batch Fecundity } & \multicolumn{3}{c}{ Condition Index } & \multicolumn{3}{c}{ Gonado-Somatic Index } \\
\hline & Estimate & SE & $p$ & Estimate & SE & $p$ & Estimate & SE & $p$ \\
\hline Intercept & & & & 2.1680917 & 0.3079701 & $<0.0001$ & & & \\
$\mathrm{~T}$ & -5.725703 & 1.254891 & $<0.0001$ & -0.0053596 & 0.0014593 & $<0.001$ & -0.5523669 & 0.1249885 & $<0.0001$ \\
$\mathrm{~S}$ & 3.378869 & 0.718607 & $<0.0001$ & -0.0365113 & 0.0143465 & $<0.05$ & 0.3900672 & 0.0715741 & $<0.0001$ \\
$\mathrm{~T}^{2}$ & 0.118154 & 0.023322 & $<0.0001$ & & & & 0.0108684 & 0.0023229 & $<0.0001$ \\
$\mathrm{~S}^{2}$ & -0.035223 & 0.007655 & $<0.0001$ & 0.0004007 & 0.0001541 & $<0.05$ & -0.0041510 & 0.0007624 & $<0.0001$ \\
\hline $\mathrm{R}^{2}$ & & 0.90 & & & 0.25 & & & 0.97 & \\
\hline RSE & & & & 0.0458 & & & 0.4140 \\
\end{tabular}

\section{Discussion}

Understanding the spawning biology of fish species in extreme environments, such as inverse hypersaline estuaries, is crucial for evaluating the reproductive potential of stocks at the outer ranges of their physiological capacity [8,32]. For the first time in marine fishes, the optimal salinity for egg production was observed to be in hypersaline waters (salinity 42-51). Obtained results on fecundity variations in E. fimbriata suggest that the species is well adapted to extreme fluctuations in environmental conditions through highly variable reproductive output. However, the observed increase in reproductive potential under hypersaline conditions is accompanied by a trade-off between batch fecundity, gonadal energy storage, and somatic growth.

The length spectrum of females sampled for the present study is comparable to the ones obtained in former studies conducted in the same geographical area $[25,48]$. The observed differences in length/weight relationships revealed that females sampled in the Saloum River's middle reaches (Foundiougne) generally had a lower weight at a certain length when compared to their counterparts sampled at the Saloum River's mouth (Djifer) and at the Senegalese Coast (Joal). Females (stage I-IV) caught at Foundiougne were in a significantly worse nutritional condition (K) in all months when compared to specimens caught at Joal and Djifer. In specimens sampled inside the estuary seasonal differences in $\mathrm{K}$ became apparent with notable peaks in February (cool and dry season) and July (warm and dry season). This may hint towards a shift from a marine to a hypersaline phytoplankton community, and thus to temporal differences in food item quality/abundance [49,50]. Also, females spawning in the estuary's middle reaches were exhibiting lower condition indices $\left(\mathrm{K}_{\text {hyd }}\right)(1.37 \pm 0.08)$ than the ones reproducing in the open ocean $(1.56 \pm 0.12)$. It has been proposed before that mature fish might travel upstream to spawn, whereas juveniles and immature females may instead tend to move downstream to forage under marine conditions [51,52]. An energetically expensive migratory behaviour towards spawning grounds has been described for the anadromous American shad (Alosa sapidissima, Wilson 1811) [7,53,54] and for the Pontic shad (Alosa immaculata, Bennett 1835) [55]. The expected travelling distances of female E. fimbriata in West African waters, however, are much smaller than those reported for the Alosa species in North America or Eastern Europe and are therefore not necessarily suitable to explain this discrepancy in somatic energy budget. High energetic costs for osmoregulation processes under hypersaline conditions within the middle reaches of the Saloum River and/or differences in stock densities between the sea and the estuary might rather serve as explanations for the observed differences in the condition index $[25,56]$. Still, elevated stock sizes appear to have negative effects on fecundity in clupeids [16].

Spawning females were observed at Foundiougne during the entire study period, at Djifer from February until July, and at Joal from March until May. These results are in good agreement with the species' temporally limited spawning periods defined in past studies [25,43]. It has been suggested before that seasonally varying hydrographic conditions (changes in water temperature and salinity) 
play a critical role in the timing and intensity of spawning in clupeid fishes [57-59]. Locally varying spawning times therefore hint towards favourable hydrographic conditions for offspring survival at the coast after the onset of upwelling at the beginning of the year. Given the species' prolonged spawning season, however, conditions are most likely favourable for spawning and early life stages survival in the Saloum River's middle reaches all year around. Thus, an examination of E. fimbriata's batch fecundity in relation to respective physical parameters could shed some light on observed energetic disparities and the species' spawning strategy.

High variances in $\mathrm{ABF}$ were previously reported for E. fimbriata throughout the entire West African coast $[36,60,61]$. Our results further underline the species' high phenotypic plasticity in this particular reproductive trait $[62,63]$. Further, females sampled at Foundiougne produced significantly more hydrated oocytes at a certain length/weight than their counterparts sampled at Djifer and Joal. Thus, females spawning inside the Saloum River's middle reaches were more fecund for the same size. A closer look at the observed spatial and monthly variability in RBF might explain the observed differences in ABF. Comparable to past studies, calculated values for mean RBF also varied widely between months $[25,44,52]$. Females sampled at elevated salinities were producing four times more oocytes $\left(294 \pm 137\right.$ oocytes $\left.^{-1}\right)$ than their oceanic counterparts $\left(74 \pm 65\right.$ oocytes $\left.\mathrm{g}^{-1}\right)$. Clupeid fishes are known to adjust reproductive strategies to local conditions $[7,64,65]$ and thus produce egg quantities and egg sizes that favour offspring survival under the environmental conditions in which they are to develop $[66,67]$.

Length-specific fecundities of experimentally starved Pacific herring (Clupea pallasii pallasii, Valenciennes 1847) were similar to those of fed fish, but the unfed fish had higher weight-specific fecundities, corresponding to a greater loss of somatic tissue during captivity [68]. Consequently, calculated RBF was highest among the unfed/starving fish. In the case of E. fimbriata, elevated RBF as an adaptive response to starvation is unlikely, since no contradictory effect of female size on ABF could be observed. Additionally, primary production within tropical mangrove ecosystems has been amply described as comparably high and thus a shortage in food items is unlikely [69,70].

For estimating the correlation of spawning parameters and water temperature we used satellite-derived sea surface temperatures, as well as in situ surface temperatures, for inland waters. Due to the range in observed surface water temperatures from 18 to $31{ }^{\circ} \mathrm{C}$ we accepted the satellite-derived values with an accuracy of $\pm 0.5{ }^{\circ} \mathrm{C}$ for our purposes [71]. The multiple linear regression models for $\mathrm{RBF}$ and the $\mathrm{I}_{\mathrm{G}}$ indicate that $E$. fimbriata is producing increasing numbers of oocytes, and in consequence the ratio of gonad weight to ovary-free body weight is increasing along a rising temperature and salinity gradient. The negative, quadratic effects of temperature and salinity on RBF and $\mathrm{I}_{\mathrm{G}}$, on the other hand, illustrate that elevated metabolic rates and osmoregulation processes play a crucial role in limiting the species' reproductive potential under hypersaline conditions. Because $K_{\text {hyd }}$ is negatively correlated with temperature and salinity, a trade-off effect between batch fecundity/gonadal energy storage and the female's somatic condition can be concluded. Further evidence is provided by the fact that the mean monthly condition of stage $\mathrm{V}$ females decreased significantly while mean RBF increased in concert with rising temperature and salinity gradients throughout most of the sampling period. At Foundiougne, spawner condition only improved again in October when salinity decreased due to the prevailing rainy season. These observations lead to the conclusion that the reproductive investment of well-adapted clupeids is not necessarily dependant on fish size, but rather on the respective spawning environment. High variability in reproductive output through phenotypic plasticity seems to allow fast adjustment to drastically varying environments, and may therefore be beneficial for recruitment in clupeids [7,16].

Obtained results give strong evidence that elevated salinities (42-51), in synergy with high water temperatures $\left(26-30{ }^{\circ} \mathrm{C}\right)$, directly affect the condition, reproductive investment, and consequently the reproductive potential of mature female E. fimbriata. For the first time in clupeid fishes, the current study shows a spawning optimum at salinities that far exceeded marine conditions. Conversely, the marine Brazilian menhaden (Brevoortia aurea, Spix \& Agassiz 1829) population exhibits a spawning 
preference at salinities which are far lower than marine (salinity 10-25) in order to ensure the retention of early life stages at the estuary's mouth where offspring survival chances are most likely higher [72].

Embryonic developmental times and hatching rates are not only affected by water temperatures, but also by salinities [73]. While former studies showed that the survival of early life history stages is possible in either high temperature [74] or high salinity regimes [75], egg development, hatching, and larval survival are prone to impairment under combined high temperature and high salinity conditions [21,22]. Certain temperature and salinity combinations might trigger reproduction in clupeids inhabiting variable hypersaline environments, comparable to the isolated effect of temperature on temperate [58], or even on other, tropical species [19]. The observed reproductive strategy may therefore aim towards spawning in a favourable environmental window [76,77], ensuring the survival of well-adapted offspring through enhanced quality in food items and/or predator avoidance during the consecutive weeks [78]. On the contrary, it may also be hypothesised that this strategy might overcompensate for high offspring mortality under these rather extreme conditions [79].

In consequence, the spawning effort combined with elevated metabolic rates under high temperature and energy allocation to the osmoregulation processes under hypersaline conditions are most likely too high to be compensated for by nutritional intake and are therefore at the expense of somatic growth in clupeids $[4,20]$. This trade-off mechanism will ultimately limit the reproductive potential of clupeid fishes inhabiting estuarine environments impacted by global change. The observed high variability in the reproductive potential of E. fimbriata seems to be a viable strategy in order to adjust to the drastically changing and rather extreme environments such as hypersaline estuaries. Future examinations of food webs in hypersaline environments, in combination with laboratory experiments on egg survival and developmental rates under different temperature and salinity regimes, are necessary to understand the underlying mechanisms. Even further, future application of a Dynamic Energy Budget model may foster our understanding of the observed discrepancies. It would allow for a closer investigation of energy allocations to determine to which degree they are associated with water temperature and salinity in this species [80].

\section{Materials and Methods}

\subsection{Sampling Sites}

Located $100 \mathrm{~km}$ south of Dakar (between $13^{\circ} 55^{\prime}$ and $14^{\circ} 10^{\prime} \mathrm{N}$, and $16^{\circ} 03^{\prime}$ and $16^{\circ} 50^{\prime} \mathrm{W}$ ), the Sine Saloum delta is comprised of three main branches, the Saloum, the Diomboss, and the Bandiala (Figure 5). An extended dry season is characteristic for this region, cool from November to March, and warm from April to June. The wet and warm season is rather short, lasting from July to October.

Total rainfall has been steadily decreasing since the 1920 's, with a particularly severe decline since 1961. Combined effects of tides, reduced river run-off, intense evaporation, and shallow waters in the estuary's mouth have led to high salinity and an overall inversion of the salinity gradient [45]. Consequently, salinity increases upstream in all seasons in the Saloum River. In the river's upper reaches, surface water temperatures thus exceed $30^{\circ} \mathrm{C}$ and salinity levels are two to three times higher than those of seawater by the end of the dry season [81].

Sampling took place at the Senegalese coast and inside the Saloum River from February to October 2014, during the peak of E. fimbriata's spawning season [25,52]. Three different sites were sampled: Joal (Senegalese coast, $14^{\circ} 9.1^{\prime} \mathrm{N} ; 16^{\circ} 51.7^{\prime} \mathrm{W}$ ), Djifer (Saloum River's mouth, $13^{\circ} 57.8^{\prime} \mathrm{N}$; $16^{\circ} 44.8^{\prime} \mathrm{W}$ ), and Foundiougne (upstream Saloum River, $14^{\circ} 8.1^{\prime} \mathrm{N} ; 16^{\circ} 28.1^{\prime} \mathrm{W}$ ) (Figure 5). 


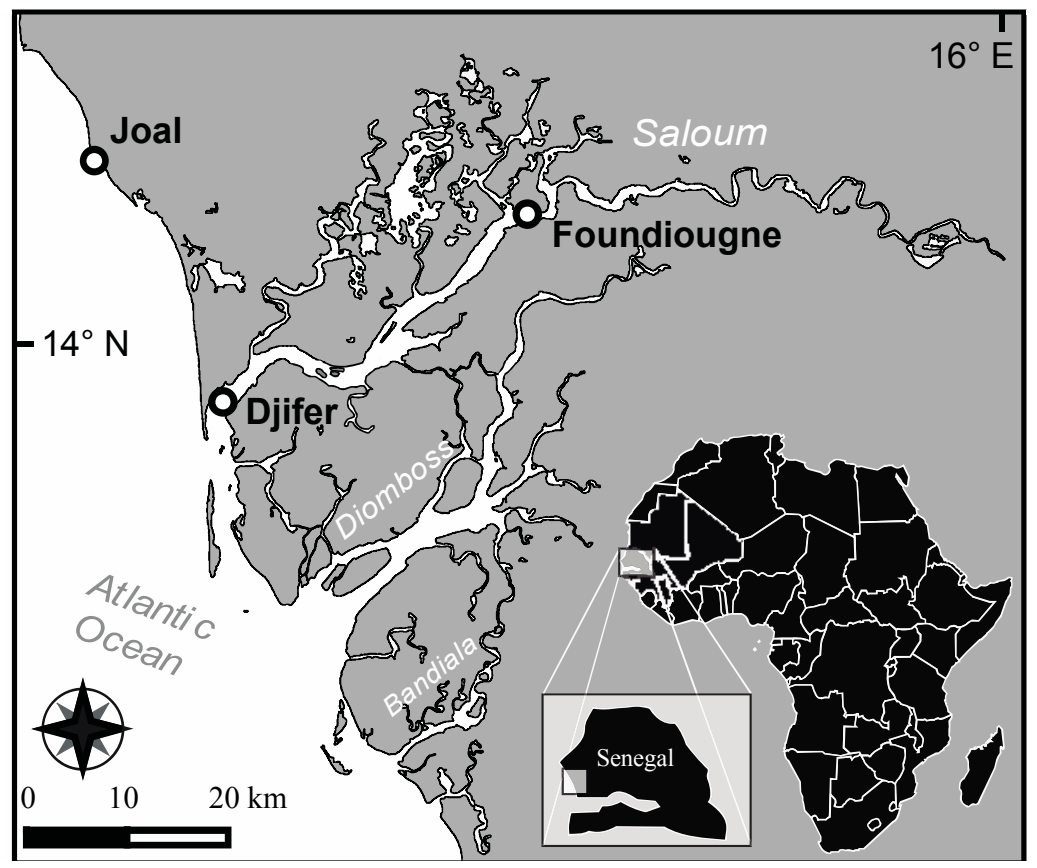

Figure 5. Map of the Senegalese coast and the Sine Saloum estuary including sampling sites: Joal, Djifer, and Foundiougne.

\subsection{Environmental Parameters}

To get an overview of the seasonal changes of environmental conditions, water temperatures and salinity were measured. Because the upwelling area in front of Senegal (mean water depth on the shelf $<20 \mathrm{~m}$ ) and the Saloum River (mean depth $<10 \mathrm{~m}$ ) are well mixed water bodies, surface water temperatures and salinities were employed [82-84]. Moderate-resolution Imaging Spectroradiometer (MODIS), satellite-derived (Aqua, level 2, 0.1 degrees) sea surface temperatures (https: / / oceancolor. gsfc.nasa.gov /) were assessed for Joal (20 km radius) and Djifer once per sampling week to enhance spatial coverage by avoiding cloud cover. As no remote sensing data for inland waters were available, the Saloum River's surface water temperatures were recorded in situ once per sampling week with a digital thermometer (ama-digit ad 15th; precision $0.4 \%$; accuracy $0.4 \%$ ). For all stations, salinity was measured with a handheld refractometer (Aqua Medic; precision $0.7 \%$, accuracy $0.2 \%$ ) using the Practical Salinity Scale (PSS-78). Monthly means in MODIS satellite-derived (Aquarius, level 3, 0.5 degrees) sea surface salinities (https: / / oceancolor.gsfc.nasa.gov/) were used to double-check the coastal ocean's salinity in a radius of $20 \mathrm{~km}$ around Joal.

\subsection{Fish Sampling}

Fish were caught with gill nets (32-36 mm mesh size) by local fishermen, and immediately stored on crushed ice after landing. To ascertain the species' batch fecundity, ca. 1000 fish per sampling site and month were examined in order to find stage V females. Staging of fish was conducted macroscopically [60]. In order to discriminate between mature females with ovaries containing fully hydrated oocytes (stage V) and females that had recently spawned (spent, stage VI), further descriptions on maturity stages in clupeid fishes were consulted $[85,86]$. Running ripe females were not sampled, since they might have released part of the egg batch. Overall, the ovaries of 189 specimens were dissected and transferred to a $4 \%$ borax buffered formaldehyde and freshwater liquid.

Fish were measured by fork length to avoid falsifications due to fin damage. Accordingly, 100 fish with intact caudal fins were measured twice, by fork length as well as total length, to obtain a length coefficient for subsequent length data transformation. Conversions of fish fork length $\left(\mathrm{L}_{\mathrm{F}}\right)$ to total length $\left(\mathrm{L}_{\mathrm{T}}\right)$ were conducted using the equation $\mathrm{L}_{\mathrm{T}}=1.0007 \times \mathrm{L}_{\mathrm{F}}+3.9$ (Student's $t$-test, $p<0.05, \mathrm{r}^{2}=0.83$ ). 


\subsection{The Condition Index and the Gonado-Somatic Index}

In order to access the nutritional status of immature female fish (Stage I-IV), a condition index (K) Equation (2) was calculated for each individual using wet weight $\left(\mathrm{W}_{\mathrm{W}}, \pm 0.1 \mathrm{~g}\right)$, total length $\left(\mathrm{L}_{\mathrm{T}}\right.$, nearest $\mathrm{mm}$ ) [87], and $\mathrm{b}$ of the length-weight relationship. The $\mathrm{K}_{\text {hyd }}$ (Equation (3)) and the $\mathrm{I}_{\mathrm{G}}$ (Equation (4)) of hydrated female spawners (Stage V) were based on the ovary-free body weight ( $\mathrm{W}_{\mathrm{OF}}$, $\pm 0.1 \mathrm{~g})$ and the ovary weight $\left(\mathrm{W}_{\mathrm{Ov}}, \pm 0.0001 \mathrm{~g}\right)$ [88]. These indices were used as proxies for the somatic and gonadal energy storage of female spawners.

$$
\begin{gathered}
K=W_{\mathrm{W}} \times L_{\mathrm{T}}^{-\mathrm{b}} \times 1000 \\
K_{\mathrm{hyd}}=W_{\mathrm{OF}} \times{L_{\mathrm{T}}}^{-\mathrm{b}} \times 1000 \\
I_{\mathrm{G}}=W_{\mathrm{Ov}} \times W_{\mathrm{OF}}{ }^{-1} \times 100
\end{gathered}
$$

\subsection{Absolute Batch Fecundity and Relative Batch Fecundity}

E. fimbriata is an indeterminate batch spawner [44]. Therefore, measuring the number of hydrated oocytes produced in a single spawning batch is the only useful method to determine fecundity [89]. $\mathrm{ABF}$ was consequently assessed gravimetrically using the hydrated oocyte method for indeterminate spawners $[16,90,91]$. ABF was divided by $\mathrm{W}_{\mathrm{OF}}$ to calculate the RBF [13]. Due to high variability in E. fimbriata's batch fecundities, we re-analysed the $10 \%$ of the sampled ovaries containing the least amount of oocytes. We measured the diameters of seemingly hydrated oocytes within the questionable samples and compared these values with the diameter values of hydrated oocytes stored in ovaries with high absolute batch fecundities, which were sampled in the same months using ANOVA techniques. Ovaries containing oocytes with significantly lower diameters were rejected. Only hydrated oocytes with a diameter greater than $0.80 \mathrm{~mm}$ were taken into account for fecundity analysis. Additionally, ovaries containing oocytes without significant differences in diameter were re-examined macroscopically.

\subsection{Statistical Analysis}

The relationships between $\mathrm{L}_{T}$ and $\mathrm{W}_{\mathrm{W}}$ were described using power functions. Data on $\mathrm{L}_{\mathrm{T}}$ and $W_{W}$ were log-transformed in order to test for spatial differences in the resulting linear growth models. The assumption of parallel lines was tested and intercepts were subsequently compared using ANCOVA [92]. The parameters of the linear regressions for $\mathrm{L}_{\mathrm{T}}$ and $\mathrm{ABF}$, as well as for OFBW and ABF, were also compared using ANCOVA. Regression coefficients for the relationships between FL and $\mathrm{L}_{\mathrm{T}}$, as well as $\mathrm{L}_{\mathrm{T}}$ and $\mathrm{W}_{\mathrm{W}}$ were tested for significance using Student's $t$-tests. Differences in $\mathrm{K}$ were tested using ANOVA, with both sampling month as well as sampling location as independent variables. Additionally, for each sampling location, differences in $\mathrm{K}_{\text {hyd }}, \mathrm{I}_{\mathrm{G}}$, and RBF were tested applying ANOVA with the sampling month as an independent variable. Given the fact that ANOVA techniques are quite robust against small sampling sizes if the assumption of homogeneity of variances is met [93], data on $\mathrm{I}_{\mathrm{G}}$ and RBF were square root transformed [16,94]. In cases where significant differences were detected, post hoc multiple comparisons were performed. The employed Tukey HSD test calculates $p$-values that have been corrected for the number of independent pair-wise comparisons that are possible given the number of factor levels. Statistical analyses were carried out using JMP 11.0.1 (SAS Institute Inc., Cary, NC, USA, www.jmp.com).

Since tolerance curves describing physiological processes are a common tool in ecology, predictive models were used, which allowed a comparison between E. fimbriata's spawning preferences and condition optimum $[77,95,96]$. After interactions between independent variables were tested, we employed multiple linear regressions to reveal the respective responses of $\mathrm{RBF}, \mathrm{I}_{\mathrm{G}}$, and $\mathrm{K}_{\text {hyd }}$ to temperature $\left(T, T^{2}\right)$ and salinity $\left(S, S^{2}\right)$. The resulting minimal adequate models were tested for the constancy of variances (residuals against fitted values; left hand side plots in Appendix B 
Figures A1-A3) and the normal distribution of their residuals (normal quantile-quantile plot; right hand side plots in Appendix B Figures A1-A3; and Anderson-Darling tests and Cramer-von-Mises tests with a significance threshold of $p=0.1$ ). Where any of these two assumptions were violated, we transformed the response variable and re-ran the multiple regression. This was the case for all three dependent variables, and thus square-root transformations were applied. All final minimal adequate models show constancy of variance and normal distribution of their residuals (Appendix $B$ Figures A1-A3). Models were built in RStudio: Integrated Development for R 1.0.44 (RStudio, Inc., Boston, MA, USA, www.rstudio.com).

\section{Conclusions}

Albeit hydrographic conditions in the middle reaches of the Saloum River are favourable for spawning in E. fimbriata all year around, temporal and spatial variations in spawner condition, gonado-somatic index, and batch fecundity could be observed and linked to heterogeneous environmental conditions. Our results show that E. fimbriata has to budget a significant amount of energy towards elevated metabolic rates and osmoregulation processes in an effort to spawn under high temperature/hypersaline conditions. The observed trade-off mechanism between the somatic energy budget and reproductive investment ultimately limits the species' reproductive potential inside the estuary. Due to its high adaptive potential and euryhaline physiology, E. fimbriata is, so far, likely to benefit from the severe impacts of global change on its spawning habitat by potentially outcompeting other pelagic fish species. However, a further decrease in precipitation and a concerted elevation of ambient salinities will have negative impacts on the species' habitat size, reproductive potential, and eventually on its stock size.

Acknowledgments: This study was conducted within the framework of the trilateral project "Ecosystem approach to the management of fisheries and the marine environment in West African waters" (funding no. 01DG12073B). The authors are grateful to Constanze von Waldthausen and Stefanie Bröhl who were of great help during the preparations of the field sampling campaigns. We would like to thank Papa Ndiaye, Khady Diouf, Khady Diop, Ousseynou Samba, Luc Badji, and all employees and students with the LABEP-AO at the IFAN in Dakar for their valuable support during the course of the field sampling campaign and the subsequent laboratory analysis. We are thankful to Amadou Diagne for being a patient translator and for providing safe transportation in the field. We thank Amanda Ford, Carola Wagner, Mithra-Christin Hajati, Holger Haslob, Matthias Birkicht, and Myron Peck for advice and for reviewing earlier versions of this manuscript. Finally, we would like to thank Patrice Brehmer, without whose constant support and advice this study would not have been possible.

Author Contributions: J.D. and W.E. fathered the original research idea and designed the field sampling campaign; J.D. and H.S. carried out the sampling; J.D. performed the fecundity analyses; J.D., M.T., and M.S. analyzed the data; J.D. wrote the paper.

Conflicts of Interest: The authors declare no conflict of interest. 


\section{Appendix A}

Table A1. Range in total length $\left(\mathrm{L}_{\mathrm{T}}\right)$, mean values for condition factor $\left(\mathrm{K}_{\text {hyd }}\right)$, gonado-somatic index $\left(\mathrm{I}_{\mathrm{G}}\right)$, relative batch fecundity $(\mathrm{RBF})$, and the range in absolute batch fecundity $(\mathrm{ABF})$ of female E. fimbriata by sampling site and month. Letters indicate Tukey Honest Significant Difference post hoc test results, values not sharing the same letters are significantly different from each other $(p<0.05)$.

\begin{tabular}{|c|c|c|c|c|c|c|c|c|c|c|c|}
\hline Site & $L_{\mathrm{T}}(\mathrm{cm})$ & & February & March & April & May & June & July & August & September & October \\
\hline \multirow{4}{*}{$\stackrel{\pi}{\varrho}$} & \multirow{4}{*}{$23.1-27.5$} & $\mathrm{~K}_{\text {hyd }}$ & & $1.56( \pm 0.12)$ & $1.51( \pm 0.09)$ & $1.51( \pm 0.10)$ & & & & & \\
\hline & & $\mathrm{I}_{\mathrm{G}}$ & & $7.43( \pm 4.32)$ & $6.97( \pm 2.05)$ & $7.68( \pm 3.90)$ & & & & & \\
\hline & & RBF & & $72.21( \pm 144.48)$ & $44.74( \pm 16.73)$ & $79.33( \pm 76.024)$ & & & & & \\
\hline & & $\mathrm{ABF}$ & & $3337-31,052$ & 4824-10,877 & $3316-66,375$ & & & & & \\
\hline \multirow{4}{*}{ 产 } & \multirow{4}{*}{$20.8-26.9$} & $\mathrm{~K}_{\text {hyd }}$ & $1.58( \pm 0.13)$ & $1.61( \pm 0.03)$ & $1.57( \pm 0.12)$ & & $1.57( \pm 0.12)$ & $1.46( \pm 0.11)$ & & & \\
\hline & & $\mathrm{I}_{\mathrm{G}}$ & $10.32( \pm 3.08)^{\mathrm{a}}$ & $7.20( \pm 4.19)^{\text {ab }}$ & $5.66( \pm 2.16)^{\mathrm{b}}$ & & $7.82( \pm 4.44)^{\mathrm{ab}}$ & $12.70( \pm 2.08)^{\mathrm{a}}$ & & & \\
\hline & & RBF & $145.05( \pm 76.78)^{\mathrm{ab}}$ & $82.29( \pm 54.61)^{\mathrm{bc}}$ & $64.53( \pm 50.97)^{\mathrm{c}}$ & & $99.68( \pm 97.95)^{\mathrm{bc}}$ & $290.15( \pm 100.05)^{\mathrm{a}}$ & & & \\
\hline & & $\mathrm{ABF}$ & $6941-39,490$ & $6126-17,630$ & $2200-36,745$ & & $2724-27,222$ & $17,151-35,693$ & & & \\
\hline \multirow{4}{*}{ 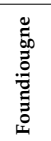 } & \multirow{4}{*}{$19.9-28.3$} & $\mathrm{~K}_{\text {hyd }}$ & $1.58( \pm 0.06)^{\mathrm{a}}$ & $1.47( \pm 0.17)^{\mathrm{a}}$ & $1.49( \pm 0.11)^{\mathrm{ab}}$ & $1.45( \pm 0.05)$ abc & $1.44( \pm 0.13)$ abc & $1.47( \pm 0.07)^{\mathrm{a}}$ & $1.39( \pm 0.11)^{\text {bc }}$ & $1.32( \pm 0.06)^{\mathrm{c}}$ & $1.37( \pm 0.08)^{\mathrm{c}}$ \\
\hline & & $\mathrm{I}_{\mathrm{G}}$ & $12.17( \pm 3.88)^{\text {abc }}$ & $10.16( \pm 2.90)^{\text {abc }}$ & $6.73( \pm 2.11)^{\mathrm{C}}$ & $8.61( \pm 4.55)^{\mathrm{abc}}$ & $8.91( \pm 2.11)^{\mathrm{abc}}$ & $10.92( \pm 4.84)^{\text {abc }}$ & $9.15( \pm 3.95)^{\mathrm{bc}}$ & $13.00( \pm 4.36)^{\mathrm{ab}}$ & $12.33( \pm 4.19)^{\mathrm{a}}$ \\
\hline & & RBF & $144.36( \pm 27.62)$ abc & $167.08( \pm 68.93)^{\mathrm{bc}}$ & $90.36( \pm 26.89)^{\mathrm{c}}$ & $189.96( \pm 123.84)$ abc & $197.15( \pm 112.92$ abc & $247.87( \pm 150.02)^{\text {ab }}$ & $213.04( \pm 152.06)^{\text {bc }}$ & $226.78( \pm 96.53)$ abc & $294.05( \pm 136.71)^{\mathrm{a}}$ \\
\hline & & ABF & $16,388-23,160$ & $6470-54,205$ & $6344-13,298$ & $13,173-29,889$ & $11,229-36,199$ & $3160-85,409$ & $4321-85,045$ & $19,501-37,985$ & $6162-61,270$ \\
\hline
\end{tabular}




\section{Appendix B}

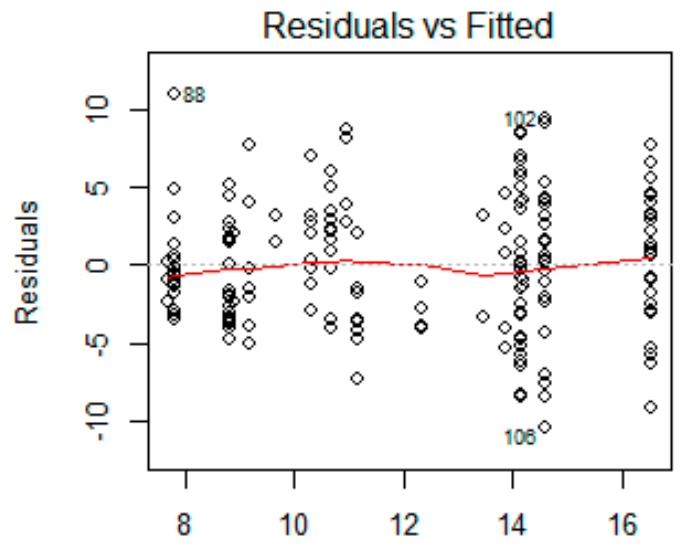

Fitted values

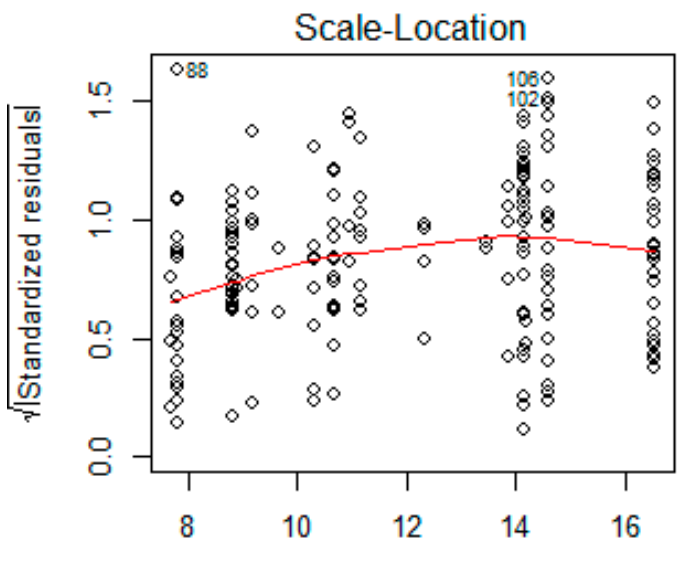

Fitted values
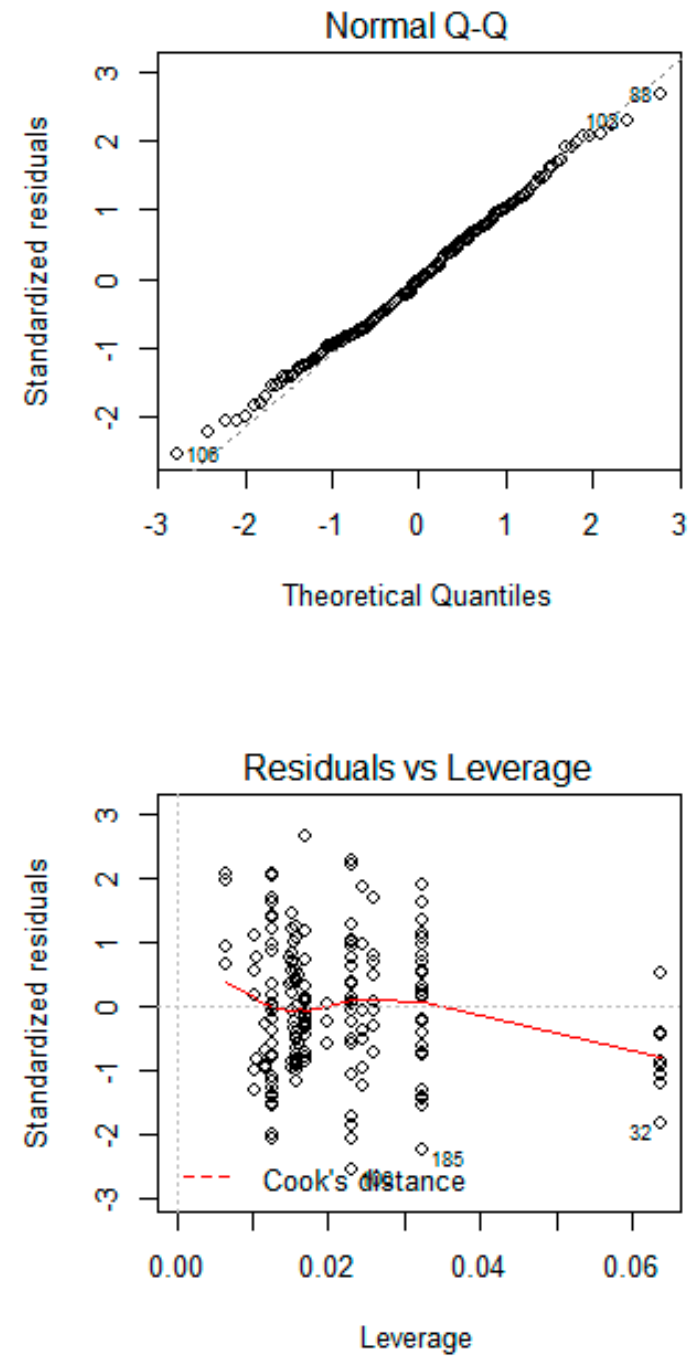

Figure A1. Residual plots for the multiple linear regression model fitted to the square root transformed data of relative batch fecundity (RBF) against surface water temperature, and surface water salinity. Anderson-Darling tests and Cramer-von-Mises tests with a significance threshold of $p=0.1$ did not show significant deviations of the residuals from a normal distribution. 

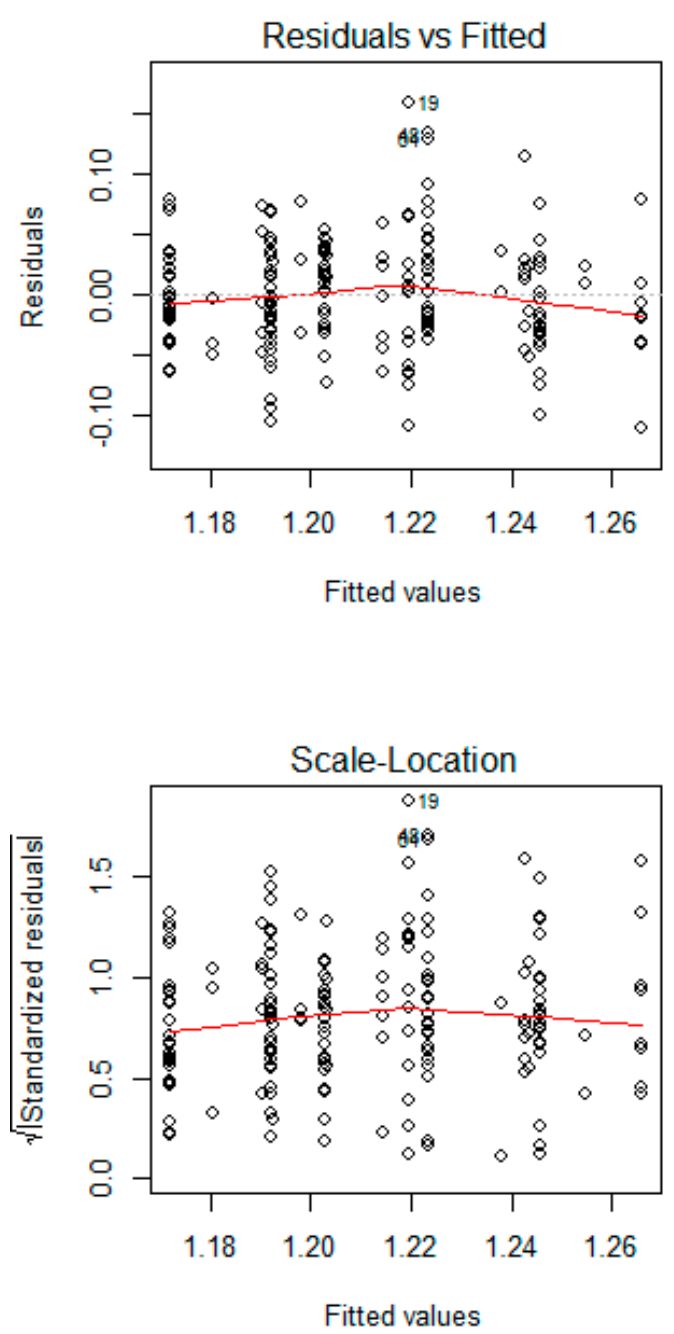
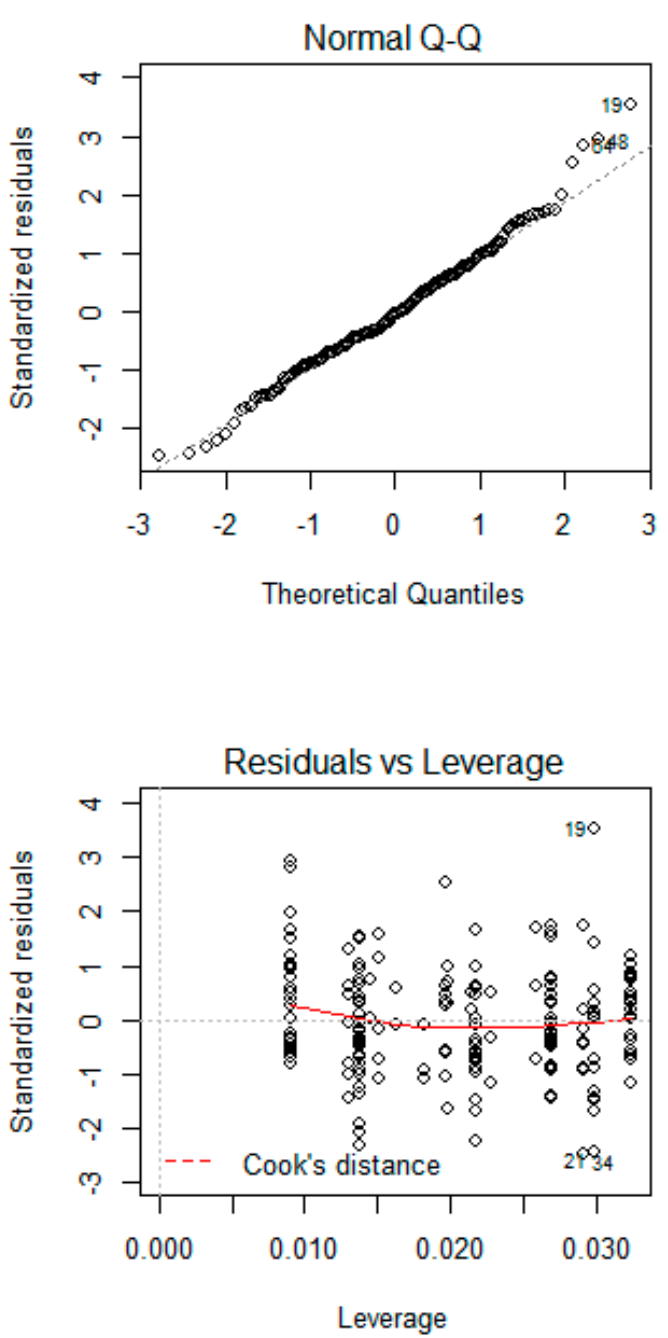

Figure A2. Residual plots for the multiple linear regression model fitted to the square-root transformed data of condition index $\left(\mathrm{K}_{\text {hyd }}\right)$ against surface water temperature, and surface water salinity. Anderson-Darling tests and Cramer-von-Mises tests with a significance threshold of $p=0.1 \mathrm{did}$ not show significant deviations of the residuals from a normal distribution. 


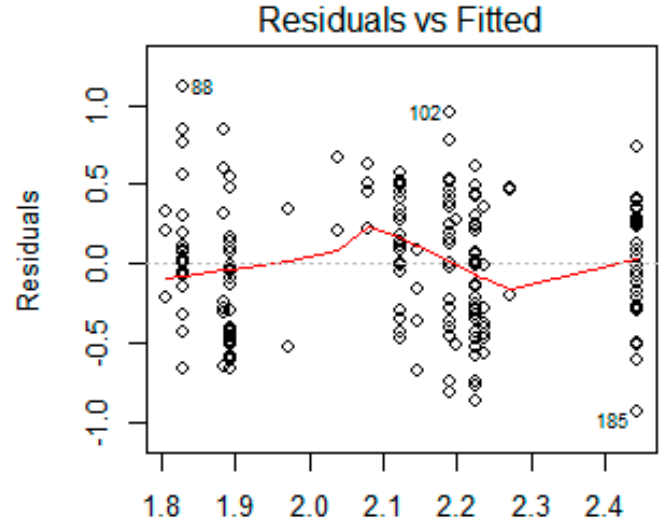

Fitted values

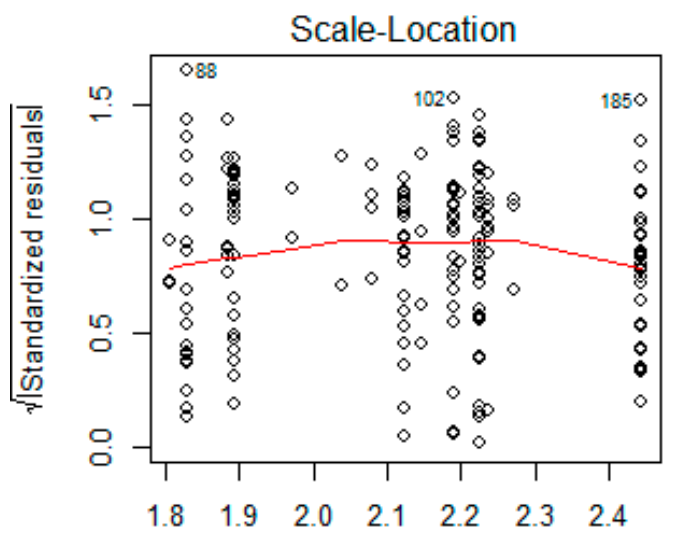

Fitted values
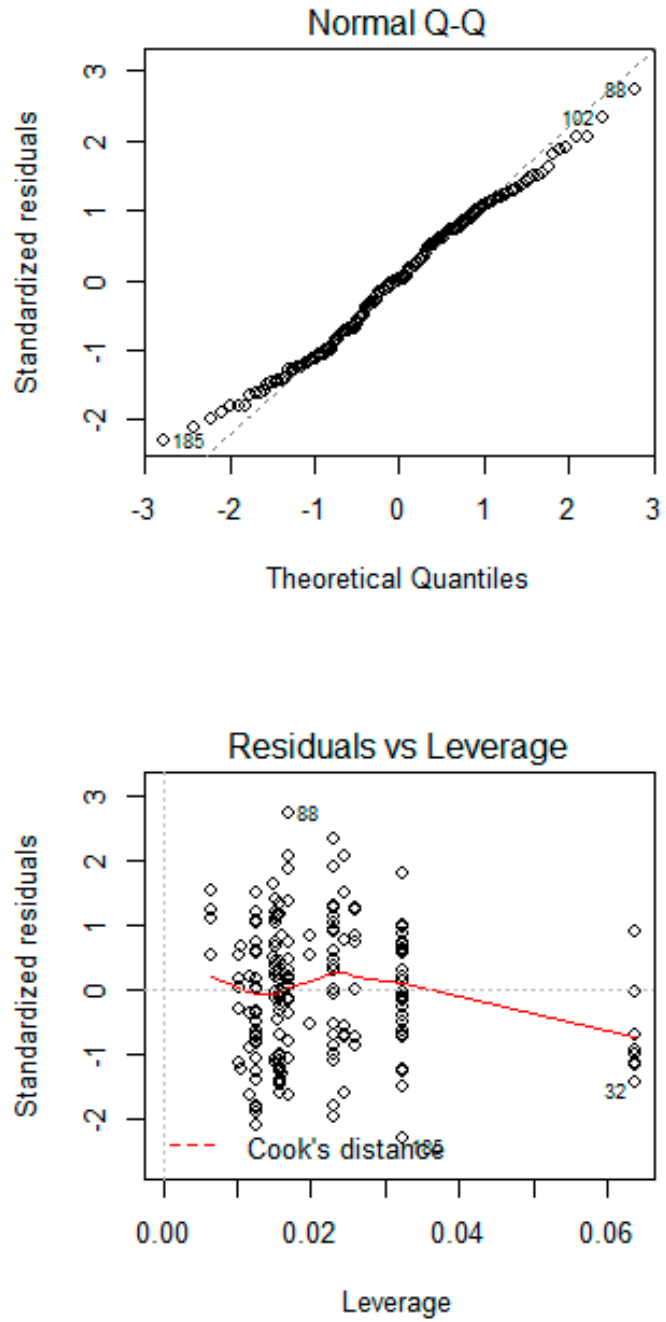

Figure A3. Residual plots for the generalized linear model fitted to the square-root transformed data of gonado-somatic index $\left(\mathrm{I}_{\mathrm{G}}\right)$ against surface water temperature, and surface water salinity. Anderson-Darling tests and Cramer-von-Mises tests with a significance threshold of $p=0.1$ did not show significant deviations of the residuals from a normal distribution. 

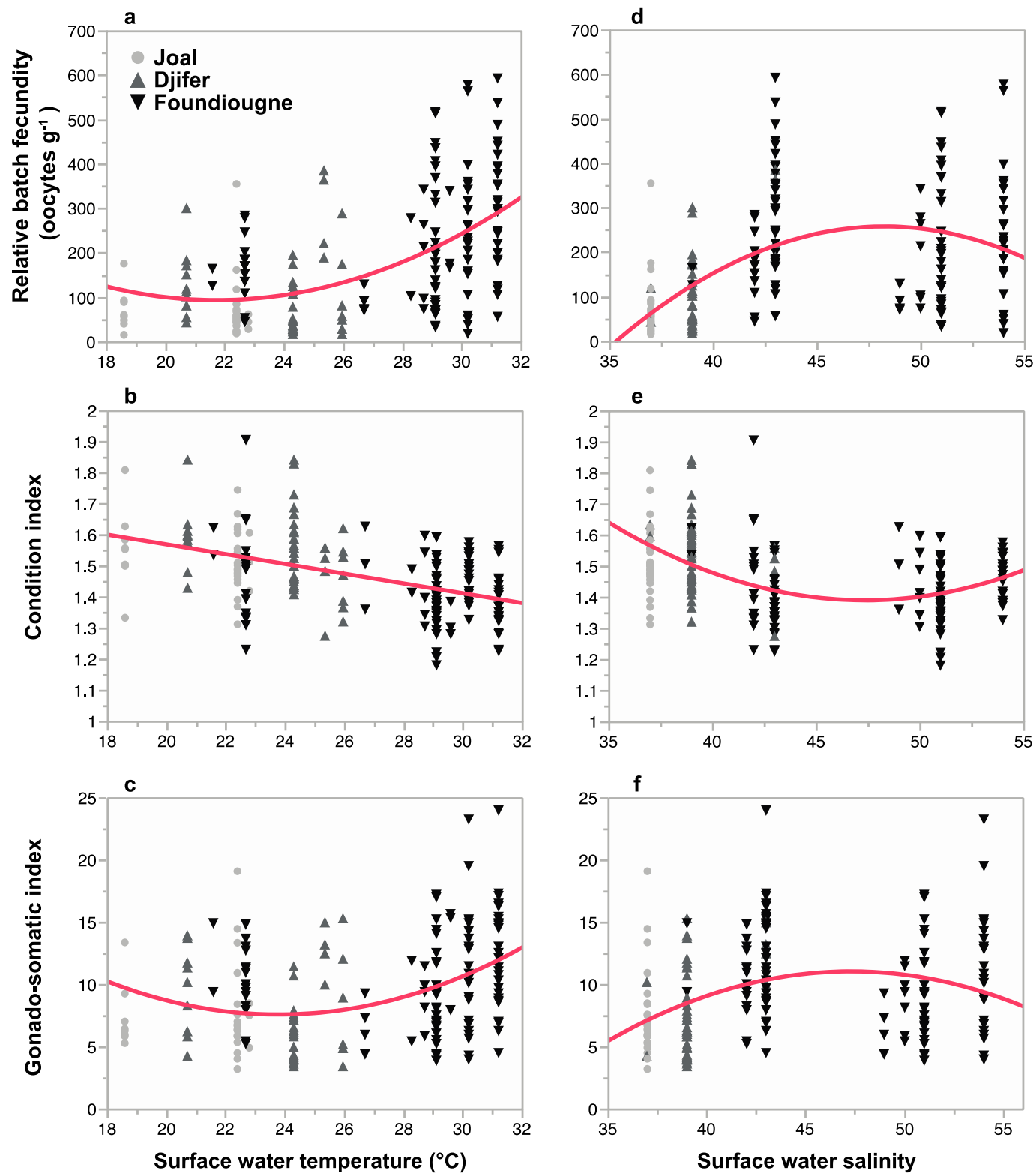

Figure A4. Relationships between relative batch fecundity (RBF), condition index $\left(\mathrm{K}_{\text {hyd }}\right)$, and gonado-somatic index $\left(\mathrm{I}_{\mathrm{G}}\right)$ with surface water temperature $(\mathbf{a}-\mathbf{c})$ and surface water salinity $(\mathbf{d}-\mathbf{f})$ in E. fimbriata. Females were sampled at Joal (Senegalese coast), Djifer (Saloum River's mouth), and Foundiougne (Saloum River's middle reaches).

\section{References}

1. Kucera, C.J.; Faulk, C.K.; Holt, G.J. The effect of parental acclimation to spawning salinity on the survival of larval Cynoscion nebulosus. J. Fish Biol. 2002, 61, 726-738. [CrossRef]

2. Nissling, A.; Johansson, U.; Jacobsson, M. Effects of salinity and temperature conditions on the reproductive success of turbot (Scophthalmus maximus) in the Baltic Sea. Fish. Res. 2006, 80, 230-238. [CrossRef]

3. Kirschner, L.B. The energetics of osmotic regulation in ureotelic and hypoosmotic fishes. J. Exp. Zool. 1993, 267, 19-26. [CrossRef]

4. Sangiao-Alvarellos, S.; Laiz-Carrión, R.; Guzmán, J.M.; Martin del Río, M.P.; Miguez, J.M.; Mancera, J.M.; Soengas, J.L. Acclimation of $S$. aurata to various salinities alters energy metabolism of osmoregulatory and nonosmoregulatory organs. Am. J. Physiol. Regul. Integr. Comp. Physiol. 2003, 285, 897-907. [CrossRef] [PubMed] 
5. Holliday, F.G.T.; Blaxter, J.H.S. The effects of salinity on the developing eggs and larvae of the herring. J. Mar. Biol. Assoc. U. K. 1960, 39, 591-603. [CrossRef]

6. Jia, Y.; Liu, Q.; Goudie, C.A.; Simco, B.A. Survival, growth, and feed utilization of pre- and postmetamorphic american shad exposed to increasing salinity. N. Am. J. Aquac. 2009, 71, 197-205. [CrossRef]

7. Leggett, W.C.; Carscadden, J.E. Latitudinal variation in reproductive characteristics of American shad (Alosa sapidissima): Evidence for population specific life history strategies in fish. J. Fish. Res. Board Can. 1978, 35, 1469-1478. [CrossRef]

8. McBride, R.S.; Somarakis, S.; Fitzhugh, G.R.; Albert, A.; Yaragina, N.A.; Wuenschel, M.J.; Alonso-Fernández, A.; Basilone, G. Energy acquisition and allocation to egg production in relation to fish reproductive strategies. Fish Fish. 2015, 16, 23-57. [CrossRef]

9. Panfili, J.; Thior, D.; Ecoutin, J.-M.; Ndiaye, P.; Albaret, J.J. Influence of salinity on the size at maturity for fish species reproducing in contrasting West African estuaries. J. Fish Biol. 2006, 69, 95-113. [CrossRef]

10. Aykanat, T.; Thrower, F.P.; Heath, D.D. Rapid evolution of osmoregulatory function by modification of gene transcription in steelhead trout. Genetica 2011, 139, 233-242. [CrossRef] [PubMed]

11. Stearns, S.C. The Evolution of Life Histories; Oxford University Press: Oxford, UK, 1992.

12. Rogers, P.J.; Ward, T.M. Life history strategy of sandy sprat Hyperlophus vittatus (Clupeidae): A comparison with clupeoids of the Indo-Pacific and southern Australia. J. Appl. Ichthyol. 2007, 23, 583-591. [CrossRef]

13. Alheit, J. Reproductive biology of sprat (Sprattus sprattus): Factors determining annual egg production. ICES J. Mar. Sci. 1988, 44, 162-168. [CrossRef]

14. Müller, A.; Muhsin, K.; Köster, F.W. Ovarian Maturation and Batch Fecundity in Baltic Sprat from the Bornholm Basin, 1988; ICES C. M.: Copenhagen, Denmark, 1990.

15. Alekseev, F.E.; Alekseeva, E.I. Batch fecundity and daily egg production of the Baltic sprat Sprattus sprattus balticus (Clupeidae) from the southeastern part of the Baltic Sea. J. Ichthyol. 2005, 45, 93-102.

16. Haslob, H.; Tomkiewicz, J.; Hinrichsen, H.-H.; Kraus, G. Spatial and interannual variability in Baltic sprat batch fecundity. Fish. Res. 2011, 110, 289-297. [CrossRef]

17. Döring, J.; Hauss, H.; Haslob, H. Spatial and seasonal variability in reproductive investment of Baltic sprat. Fish. Res. 2017. in revision.

18. Tanasichuk, R.W.; Ware, D.M. Influence of interannual variations in winter sea temperature on fecundity and egg size in Pacific herring (Clupea harengus pallasi). Can. J. Fish. Aquat. Sci. 1987, 44, 1485-1495. [CrossRef]

19. Milton, D.A.; Blaber, S.J.M.; Rawlinson, N.J.F. Fecundity and egg production of four species of short-lived clupeoid from Solomon Islands, Tropical South Pacific. ICES J. Mar. Sci. 1995, 52, 111-125. [CrossRef]

20. Leonard, J.B.K.; Norieka, J.F.; Kynard, B.; McCormick, S.D. Metabolic rates in an anadromous clupeid, the American shad (Alosa sapidissima). J. Comp. Physiol. B Biochem. Syst. Environ. Physiol. 1999, 169, 287-295. [CrossRef]

21. Hempel, G. Early Life History of Marine Fish: The Egg Stage; University of Washington Press: Seattle, WA, USA; London, UK, 1979.

22. Martin, T.J. Interaction of salinity and temperature as a mechanism for spatial separation of three co-existing species of Ambassidae (Cuvier) (Teleostei) in estuaries on the south-east coast of Africa. J. Fish Biol. 1988, 33, 9-15. [CrossRef]

23. Pörtner, H.O.; Schulte, P.M.; Wood, C.M.; Schiemer, F. Niche dimensions in fishes: An integrative view. Physiol. Biochem. Zool. 2010, 83, 808-826. [CrossRef] [PubMed]

24. Peck, M.A.; Baumann, H.; Bernreuther, M.; Clemmesen, C.; Herrmann, J.-P.; Haslob, H.; Huwer, B.; Kanstinger, P.; Köster, F.W.; Petereit, C.; et al. The ecophysiology of Sprattus sprattus in the Baltic and North Seas. Prog. Oceanogr. 2012, 103, 42-57. [CrossRef]

25. Panfili, J.; Durand, J.-D.; Mbow, A.; Guinand, B.; Diop, K.; Kantoussan, J.; Thior, D.; Thiaw, O.T.; Albaret, J.J.; Laë, R. Influence of salinity on life history traits of the bonga shad Ethmalosa fimbriata (Pisces, Clupeida): Comparison between the Gambia and Saloum estuaries. Mar. Ecol. Prog. Ser. 2004, 270, 241-257. [CrossRef]

26. Tseng, Y.C.; Hwang, P.P. Some insights into energy metabolism for osmoregulation in fish. Comp. Biochem. Physiol. C Toxicol. Pharmacol. 2008, 148, 419-429. [CrossRef] [PubMed]

27. Woodhead, A.D. Nutrition and reproductive capacity in fish. Proc. Nutr. Soc. 1960, 19, 23-28. [CrossRef] [PubMed]

28. Hempel, G. Egg production and egg mortality in herring. Rapports et Proces-verbaux des Réunions, ICES 1971, $160,8-11$. 
29. Marshall, C.T.; Frank, K.T. The effect of interannual variation in growth and condition on haddock recruitment. Can. J. Fish. Aquat. Sci. 1999, 56, 347-355. [CrossRef]

30. Somarakis, S.; Schismenou, E.; Siapatis, A.; Giannoulaki, M.; Kallianiotis, A.; Machias, A. High variability in the Daily Egg Production Method parameters of an eastern Mediterranean anchovy stock: Influence of environmental factors, fish condition and population density. Fish. Res. 2012, 117-118, 12-21. [CrossRef]

31. De Vlaming, V.L. The effects of food deprivation and salinity changes on reproductive function in the estuarine gobiid Ffsh, Gillichthys mirabilis. Biol. Bull. 1971, 141, 458-471. [CrossRef]

32. Morgan, M.J. Integrating reproductive biology into scientific advice for fisheries management. J. Northwest Atl. Fish. Sci. 2008, 41, 37-51. [CrossRef]

33. Bainbridge, V. Food of Ethmalosa dorsalis (Cuvier and Valenciennes). Nature 1957, 179, 874-875. [CrossRef]

34. Bainbridge, V. The early life history of the bonga, Ethmalosa dorsalis (Cuvier and Valenciennes). ICES J. Mar. Sci. 1961, 3, 347-353. [CrossRef]

35. Bainbridge, V. The food, feeding habits and distribution of the bonga Ethmalosa dorsalis (Cuvier \& Valenciennes). ICES J. Mar. Sci. 1963, 28, 270-283.

36. Fagade, S.O.; Olaniyan, C.I.O. The biology of the West African shad Ethmalosa fimbriata (Bowdich) in the Lagos Lagoon, Nigeria. J. Fish Biol. 1972, 4, 519-533. [CrossRef]

37. Charles-Dominique, E.; Albaret, J.J. African Shads, with emphasis on the West African Shad Ethmalosa fimbriata. In Biodiversity, Status, and Conservation of the World's Shads; Limburg, K.E., Waldman, J.R., Eds.; American Fisheries Society Symposium 35: Bethesda, MD, USA, 2003; pp. 27-48.

38. Lozano-Ray, L. Etude systématique des Clupéidés et des Engraulidés de l’Espagne, du Maroc et du Sahara Espagnols. Rapports et Proces-verbaux des Réunions ICES 1950, 126, 7-20.

39. Paugy, D.; Lévêque, C.; Teugels, G.G. The Fresh and Brackish Water Fishes of West Africa; Publications Scientifiques du Muséum, MRAC: Paris, France, 2003.

40. Albaret, J.J.; Charles-Dominique, E. Observation d'une taille a la premiere maturation sexuelle exceptionnellement faible chez Ethmalosa fimbriata Bowdich dans une baie polluee de la lagune ebrie (Cote D’Ivorie). Doc. Sc. Cent. Rech. Océanogr. Abidjan 1982, 13, $23-31$.

41. Deme, M.; Diadhiou, H.D.; Thiam, D.; Ndiaye, V. Effort de Peche, Captures Specifiques et Valeurs Economiques des Debarquements de la Peche Continentale Dans le Fleuve Senegal, au Sine Saloum et en Casamance; Union Mondiale pour la Nature, Institut Sénégalais de Recherches Agricoles, Centre de Recherches Océanographique de Dakar-Thiaroye: Dakar, Senegal, 2001.

42. Moses, B.S.; Udoidiong, O.M.; Okon, A.O. A statistical survey of the artisanal fisheries of south-eastern Nigeria and the influence of hydroclimatic factors on catch and resource productivity. Fish. Res. 2002, 57, 267-278. [CrossRef]

43. Scheffers, W.J.; Conand, F.; Reizer, C. Étude de Ethmalosa fimbriata (Bowdich) dans la région Sénégamibienne. 1ère note: Reproduction et lieux de ponte dans le fleuve Sénégal et la région de Saint-Louis. Doc. Sc. Cent. Rech. Océanogr. Dakar-Thiaroye 1972, 44, 22.

44. Albaret, J.J.; Gerlotto, F. Biologie de l'Ethmalose (Ethmalosa fimbriata Bowdich) en Côte D'Ivoire. I.-Description de la reproduction et des premiers stades larvaires. Doc. Sci. Cent. Rech. Océanogr. 1976, 7, 113-133.

45. Pagès, J.; Citeau, J. Rainfall and salinity of a sahelian estuary between 1927 and 1987. J. Hydrol. 1990, 113, 325-341. [CrossRef]

46. Wolanski, E. An evaporation-driven salinity maximum zone in Australian tropical estuaries. Estuar. Coast. Shelf Sci. 1986, 22, 415-424. [CrossRef]

47. Ridd, P.V.; Stieglitz, T. Dry season salinity changes in arid estuaries fringed by mangroves and saltflats. Estuar. Coast. Shelf Sci. 2002, 54, 1039-1049. [CrossRef]

48. Boely, T.; Elwertowski, J. Observations préliminaires sur la pêche de Ethmalosa fimbriata (Bowdich) des eaux sénegalaises et son aspect biologique. Rapports et Proces-verbaux des Réunions ICES 1970, 1959, 182-188.

49. Nche-Fambo, F.A.; Scharler, U.M.; Tirok, K. Resilience of estuarine phytoplankton and their temporal variability along salinity gradients during drought and hypersalinity. Estuar. Coast. Shelf Sci. 2015, 158, 40-52. [CrossRef]

50. Döring, J.; Ekau, W. Using oocyte essential fatty acid composition to assess spawner reproductive potential under hypersaline conditions. Mar. Ecol. Prog. Ser. 2017, in revision.

51. Blay, J., Jr.; Eyeson, K.N. Feeding activity and food habits of the shad, Ethmalosa fimbriata (Bowdich), in the coastal waters of Cape Coast, Ghana. J. Fish Biol. 1982, 21, 403-410. [CrossRef] 
52. Charles-Dominique, E. Exposé synoptique des données biologiques sur l'ethmalose (Ethmalosa fimbriata S. Bowdich, 1825). Rev. Hydrobiol. Trop. 1982, 14, 373-397.

53. Glebe, B.; Leggett, W. Latitudinal differences in energy allocation and use during the freshwater migrations of American shad (Alosa sapidissima) and their life history consequences. Can. J. Aquat. Sci. 1981, 38, 806-820. [CrossRef]

54. Leggett, W.C.; Trump, C.L. Energetics of migration in American shad. In Animal Migration, Navigation, and Homing; Schmidt-Koenig, K., Keeton, W.T., Eds.; Springer: Berlin, Germany, 1978; pp. 370-377.

55. Navodaru, I.; Waldman, J.R. Shads of Eastern Europe from the Black Sea: Review of species and fisheries. Am. Fish. Soc. Symp. 2003, 35, 69-76.

56. Casini, M.; Kornilovs, G.; Cardinale, M.; Möllmann, C.; Grygiel, W.; Jonsson, P.; Raid, T.; Flinkman, J.; Feldman, V. Spatial and temporal density dependence regulates the condition of central Baltic Sea clupeids: Compelling evidence using an extensive international acoustic survey. Popul. Ecol. 2011, 53, 511-523. [CrossRef]

57. Isaac-Nahum, V.J.; Cardoso, R.D.D.; Servo, G.; Rossi-Wongtschowski, C.L.D.B. Aspects of the spawning biology of the Brazilian sardine Sardinella brasiliensis (Steindachner, 1879), (Clupeidae). J. Fish Biol. 1988, 32, 383-396. [CrossRef]

58. Coombs, S.H.; Smyth, T.J.; Conway, D.V.P.; Halliday, N.C.; Bernal, M.; Stratoudakis, Y.; Alvarez, P. Spawning season and temperature relationships for sardine (Sardina pilchardus) in the eastern North Atlantic. J. Mar. Biol. Assoc. U. K. 2006, 86, 1245-1252. [CrossRef]

59. Tsikliras, A.C.; Antonopoulou, E. Reproductive biology of round sardinella (Sardinella aurita) in the North-Eastern Mediterranean. Sci. Mar. 2006, 70, 281-290. [CrossRef]

60. Blay, J., Jr.; Eyeson, K.N. Observations on the reproductive biology of the shad, Ethmalosa fimbriata (Bowdich), in the coastal waters of Cape Coast, Ghana. J. Fish Biol. 1982, 21, 485-496. [CrossRef]

61. Kusemiju, K.; Onadeko, C.A. The seasonal occurrence and bionomics of the bonga, Ethmalosa fimbriata (Bowdich) off Aiyetoro Coast, Nigeria. Fish. Res. 1990, 8, 247-251. [CrossRef]

62. Jennings, S.; Beverton, R.J.H. Intraspecific variation in the life history tactics of Atlantic herring (Clupea harengus L.) stocks. ICES J. Mar. Sci. 1991, 48, 117-125. [CrossRef]

63. Ghalambor, C.K.; McKay, J.K.; Carroll, S.P.; Reznick, D.N. Adaptive versus non-adaptive phenotypic plasticity and the potential for contemporary adaptation in new environments. Funct. Ecol. 2007, 21, $394-407$. [CrossRef]

64. Irwin, E.R.; Bettoli, P.W. Introduced clupeids in a southern reservoir: More evidence for system-specific reproductive styles. Environ. Biol. Fishes 1995, 42, 151-159. [CrossRef]

65. Blaber, S.J.M.; Milton, D.A.; Pang, J.; Wong, P.; Boon-Teck, O.; Nyigo, L.; Lubim, D. The life history of the tropical shad Tenualosa toli from Sarawak: First evidence of protandry in the Clupeiformes? Environ. Biol. Fishes 1996, 46, 225-242. [CrossRef]

66. Leal, E.M.; Castro, L.R.; Gabriel, C. Variability in oocyte size and batch fecundity in anchoveta (Engraulis ringens, Jenyns 1842) from two spawning areas off the Chilean coast. Sci. Mar. 2009, 73, 59-66.

67. Kamler, E. Parent-egg-progeny relationships in teleost fishes: An energetics perspective. Rev. Fish Biol. Fish. 2005, 15, 399-421. [CrossRef]

68. Hay, D.R.; Brett, J.R. Maturation and fecundity of Pacific herring (Clupea harengus pallasi): An experimental study with comparisons to natural populations. Can. J. Fish. Aquat. Sci. 1988, 45, 399-406. [CrossRef]

69. Pagès, J.; Gadel, F. Dissolved organic matter and UV absorption in a tropical hyperhaline estuary. Sci. Total Environ. 1990, 99, 173-204. [CrossRef]

70. Jennerjahn, T.C.; Ittekkot, V. Relevance of mangroves for the production and deposition of organic matter along tropical continental margins. Naturwissenschaften 2002, 89, 23-30. [CrossRef] [PubMed]

71. Castillo, K.D.; Lima, F.P. Comparison of in situ and satellite-derived (MODIS-Aqua/Terra) methods for assessing temperatures on coral reefs. Limnol. Oceanogr. Methods 2010, 8, 107-117. [CrossRef]

72. Acha, E.M.; Macchi, G.J. Spawning of Brazilian menhaden, Brevoortia aurea, in the Río de la Plata estuary off Argentina and Uruguay. Fish. Bull. 1999, 98, 227-235.

73. Lambert, Y.; Yaragina, N.A.; Kraus, G.; Marteinsdottir, G.; Wright, P.J. Using environmental and biological indices as proxies for egg and larval production of marine fish. J. Northwest Atl. Fish. Sci. 2004, 33, 115-159. [CrossRef] 
74. Pepin, P. Effect of temperature and size on development, mortality and survival rates of the pelagic early life history stages of marine fish. Can. J. Aquat. Sci. 1991, 48, 503-518. [CrossRef]

75. Holliday, F.G.T. The effects of salinity on the eggs and larvae of teleosts. Fish Physiol. 1969, 1, $293-311$.

76. Motos, L. Reproductive biology and fecundity of the Bay of Biscay anchovy population (Engraulis encrasicolus L.). Sci. Mar. 1996, 60, 195-207.

77. Cury, P.; Roy, C. Optimal environmental window and pelagic fish recruitment success in upwelling Areas. Can. J. Fish. Aquat. Sci. 1989, 46, 670-680. [CrossRef]

78. May, R.C. Larval mortality in marine fishes and the critical period concept. In The Early Life History of Fish; Blaxter, J.H.S., Ed.; Springer: Berlin, Germany, 1974; pp. 3-19.

79. Rickman, S.J.; Dulvy, N.K.; Jennings, S.; Reynolds, J.D. Recruitment variation related to fecundity in marine fishes. Can. J. Fish. Aquat. Sci. 2000, 57, 116-124. [CrossRef]

80. Pecquerie, L.; Petitgas, P.; Kooijman, S.A.L.M. Modeling fish growth and reproduction in the context of the Dynamic Energy Budget theory to predict environmental impact on anchovy spawning duration. J. Sea Res. 2009, 62, 93-105. [CrossRef]

81. Simier, M.; Blanc, L.; Aliaume, C.; Diouf, P.S.; Albaret, J.J. Spatial and temporal structure of fish assemblages in an "inverse estuary", the Sine Saloum system (Senegal). Estuar. Coast. Shelf Sci. 2004, 59, 69-86. [CrossRef]

82. Tiedemann, M.; Brehmer, P. Larval fish assemblages across an upwelling front: Indication for active and passive retention. Estuar. Coast. Shelf Sci. 2016, 187, 118-133. [CrossRef]

83. Sloterdijk, H.; Sadio, O.; Brehmer, P.; Müller, H.; Döring, J.; Ekau, W. Composition and structure of the larval fish community related to environmental parameters in a tropical estuary impacted by climate change. Estuar. Coast. Shelf Sci. 2017, 197, 10-26. [CrossRef]

84. Saos, J.L.; Pagés, J. Mesure hydrologiques dans le Sine-Saloum. In L'estuaire et la Mangrove du Sine-Saloum: Atelier Régional Unesco-COMAR Dakar (Senégal) du 28 Février au 5 Mars 1983; Atelier Régional UNESCO-COMAR: Dakar, Senegal, 1985; pp. 7-14.

85. West, G. Methods of assessing ovarian development in fishes: A review. Mar. Freshw. Res. 1990, 41, $199-222$. [CrossRef]

86. Ter Hofstede, R.; Dickey-Collas, M.; Mantingh, I.T.; Wague, A. The link between migration, the reproductive cycle and condition of Sardinella aurita off Mauritania, north-west Africa. J. Fish Biol. 2007, 71, 1293-1302. [CrossRef]

87. Lloret, J.; Shulman, G.; Love, R.M. Description of condition indicators. In Condition and Health Indicators of Exploited Marine Fishes; John Wiley \& Sons, Ltd.: Hoboken, NJ, USA, 2014; pp. 1-16.

88. Zydlewski, J.; McCormick, S.D.; Kunkel, J.G. Late migration and seawater entry is physiologically disadvantageous for American shad juveniles. J. Fish Biol. 2003, 63, 1521-1537. [CrossRef]

89. Hunter, J.R.; Lo, N.C.H.; Leong, R.J.H. Batch fecundity in multiple spawning fishes. NOAA Tech. Rep. NMFS $1985,36,67-77$.

90. Alheit, J. Use ot the Daily Egg Production Method for estimating biomass of clupeoid fishes: A review and evaluation. Bull. Mar. Sci. 1993, 53, 750-767.

91. Olney, J.E.; McBride, R.S. Intraspecific variation in batch fecundity of American shad: Revisiting the paradigm of reciprocal latitudinal trends in reproductive traits. Am. Fish. Soc. Symp. 2003, 35, 185-192.

92. McDonald, J.H. Handbook of Biological Statistics, 2nd ed.; Sparky House Publishing: Baltimore, MA, USA, 2009.

93. Brown, M.B.; Forsythe, A.B. The small sample behavior of some statistics which test the equality of several means. Technometrics 1974, 16, 129-132. [CrossRef]

94. Schmider, E.; Ziegler, M.; Danay, E.; Beyer, L.; Bühner, M. Is it really robust? Reinvestigating the robustness of ANOVA against violations of the normal distribution assumption. Methodol. Eur. J. Res. Methods Behav. Soc. Sci. 2010, 6, 147-151. [CrossRef]

95. Huey, R.B.; Stevenson, R.D. Integrating thermal physiology and ecology of ectotherms: A discussion of approaches. Integr. Comp. Biol. 1979, 19, 357-366. [CrossRef]

96. Pörtner, H.O.; Peck, M.A. Climate change effects on fishes and fisheries: Towards a cause-and-effect understanding. J. Fish Biol. 2010, 77, 1745-1779. [CrossRef] [PubMed]

(C) 2017 by the authors. Licensee MDPI, Basel, Switzerland. This article is an open access article distributed under the terms and conditions of the Creative Commons Attribution (CC BY) license (http:/ / creativecommons.org/licenses/by/4.0/). 